\title{
A new talpid from the late Eocene of North America
}

Karen J. Lloyd and Jaelyn J. Eberle

Acta Palaeontologica Polonica 53 (3), 2008: 539-543 doi:http://dx.doi.org/10.4202/app.2008.0311

The origin and early evolution of talpids (moles, shrew-moles, and desmans) is not well understood, in large part due to the poor fossil record of early talpids. Here we report the oldest known talpid from North America, Oreotalpa florissantensis gen. et sp. nov., based upon a tiny dentary with m1-m3 discovered in upper Eocene (Chadronian) strata of the Florissant Formation, Florissant Fossil Beds National Monument, Colorado. Oreotalpa extends the North American record of talpids back by some six Ma and appears temporally correlative with the oldest documented talpids from the late Eocene of Europe. While others have postulated a Eurasian origin for talpids, discovery of Oreotalpa suggests that the evolution of the group was underway in North America by late Eocene time and raises the possibility of a North American origin.

Karen J. Lloyd [klloyd@twexp.org], University of Colorado Museum of Natural History, University of Colorado at Boulder, 265 UCB, Boulder, Colorado, 80309, USA; current address: The Wildlife Experience, 10035 South Peoria Street, Parker, Colorado, 80134, USA; Jaelyn J. Eberle [Jaelyn.Eberle@ colorado.edu], University of Colorado Museum of Natural History and Department of Geological Sciences, University of Colorado at Boulder, 265 UCB, Boulder, Colorado, 80309, USA.

This is an open-access article distributed under the terms of the Creative Commons Attribution License (for details please see creativecommons.org), which permits unrestricted use, distribution, and reproduction in any medium, provided the original author and source are credited. 